\title{
Entrepreneurial Motivation of Street Vendors in Seruni Beach, Bantaeng Regency
}

\author{
Muhammad Darwis ${ }^{1}$, Rifani Sri Wahyuni ${ }^{2}$, Muhammad Guntur ${ }^{3}$, Haedar \\ Akib $^{4}$, Risma Niswaty ${ }^{5}$ \\ Universitas Negeri Makassar ${ }^{1,2,3,4,5}$ \\ Email: muh.darwis@unm.ac.id ${ }^{1}$
}

(Received: 28 July 2020; revised: 14 August 2020; published: 23 September 2020)

\begin{abstract}
Motivation to develop a new business is required not only by self-confidence in its ability to succeed, but also by its ability to access information about entrepreneurial opportunities. This study aims to determine how the motivation to entrepreneurship street vendors in Seruni Beach, Bantaeng Regency. Data collection used through observation, interview and documentation techniques. Informants in the study were seven informants with the type of research and the approach used was a qualitative description. Data collection used through observation, interview and documentation techniques. The results showed that the motivation of the street vendors on Seruni Beach, Bantaeng Regency in terms of each indicator, starting from the entrepreneurial spirit indicator displayed by the street vendors, the results showed that there was indeed enthusiasm in a trader, an indicator of creativity whose results showed the traders had creativity, an innovative indicator whose results show that traders have innovative, risk-taking indicators of courage, the results show that traders are brave enough to take all kinds of risks in entrepreneurship.
\end{abstract}

Keywords: Motivation, entrepreneurship

\section{INTRODUCTION}

Basically, everyone has an entrepreneurial spirit and has the opportunity to become an entrepreneur (Cullen \& De Angelis, 2020; de Guimarães, Severo, \& de Vasconcelos, 2018; Hisrich, Peters, \& Shepherd, 2002; Holcombe, 1998; Rumelt, 1987). However, to start someone in entrepreneurship, they need encouragement or motivation to be able to create something of value and can be of interest to everyone.

Entrepreneurship is the process of creating something different in value by using the effort and time required to bear the financial, psychological, and social risks that accompany it, and receiving personal rewards and satisfaction. (Aparicio, Audretsch, \& Urbano, 2021; Bojica \& Fuentes, 2012; Hoque \& Awang, 2019; Naoumi marie tando, 2013; Nasution, Mavondo, Matanda, \& Ndubisi, 2011). According to Joseph in (Naoumi marie tando, 2013) said that entrepreneurship is an innovator who implements changes in the market through new combinations. This case requires some creativity and an ability to see patterns and trends that apply to becoming an entrepreneur. However, there are still many who are less creative and do not dare to take risks to open and manage businesses. Creativity and the courage to take risks are entrepreneurial personalities. Several other entrepreneurial personalities such as self-confidence, results-oriented, leadership, hard work, and many more will support the formation of human resources capable of managing 
Muh.Darwis; Entrepreneurial Motivation...|101

the business. An entrepreneur is someone who creates a business or business that is expected to be with risk and uncertainty to gain profits and develop the business by opening opportunities (Porter, 2009; Scherdin \& Zander, 2011; Shane \& Venkataraman, 2007). Entrepreneurship is the process of applying innovation and creativity in finding business opportunities carried out with enthusiasm and courage to take risks and to create jobs for others to reduce unemployment.

Someone in carrying out the entrepreneurial process is influenced by motivation because motivation is the initial capital that an entrepreneur must have and develop to achieve his goals. Motivation encourages someone in carrying out the entrepreneurial process to share into two things, namely motivation that is in oneself (intrinsic) and motivation from the surrounding environment (extrinsic) (Alfian, Niswaty, Darwis, Arhas, \& Salam, 2019; Nasrullah, Salam, Pratiwi, \& Niswaty, 2017; Reski, Niswaty, \& Saleh, 2018; Sirait, Arhas, \& Suprianto, 2019). Entrepreneurial motivation requires fighting power to succeed, willingness to learn to see the success of others, have a strong urge to overcome all obstacles in entrepreneurship (Amorós, Cristi, \& Naudé, 2020; Douglas \& Prentice, 2019; Ferreira, Loiola, \& Gondim, 2017; To, Guaita Martínez, Orero-Blat, \& Chau, 2020). Being an entrepreneur must also be able to understand the obstacles that will be explored when entrepreneurship, these obstacles include capital, age, talent, education level, failure, creativity level, and the business environment in competition. According to (Muhammad Zainul Madjid 2012) motivation is an impulse from within a person that encourages that person to do something, including becoming a young entrepreneur. Factors from within a person can be in the form of personality, attitudes, experiences, education, while factors from outside a person can be the influence of a colleague's leadership or other very complex factors.

Based on the opinion of experts, it can be concluded that motivation is a stimulus that can encourage someone to carry out activities to achieve certain goals. In general, to attract customers or consumers, creativity and innovation are needed so that these customers are interested in buying them, starting from the taste of delicious and attractive food and drinks, a clean and cool place to gather with family or friends with good service. Apart from being creative and innovative in entrepreneurship, a person must have an unyielding attitude, but there are still traders who when the cafe or sales are quiet they stop selling.

This study focuses on the Entrepreneurial Motivation of Street Vendors in Seruni Beach, Bantaeng Regency, considering that an entrepreneur needs to have self-motivation first to achieve his goals in running his business.

\section{METHOD}

The variable in this study is a single variable, namely the entrepreneurial motivation of street vendors (PKL) at Seruni Beach, Bantaeng Regency. This research uses a qualitative approach. The qualitative research method is a research method based on the post-positivism philosophy, used to examine the condition of a natural object, (as opposed to an experiment) where the researcher is the key instrument, the sampling of data sources is done purposively and snowball, the collection technique is by triangulation. (combined), the data analysis is inductive/qualitative, and the qualitative research results emphasize meaning rather than generalization.

The type of research used is descriptive research. Bachri (2010:50) Descriptive research is a study conducted with the main objective of providing an objective description or description of a situation. This type of descriptive research was chosen in this study 
because it is suitable for use in researching the Entrepreneurial Motivation of Street Vendors (PKL) in Seruni Beach, Bantaeng Regency. An activity that is quite important in the entire research process is data reduction. With data reduction, it can be seen about the meaning of the data that has been collected so that the research results will be immediately known.

\section{RESULT AND DISCUSSION}

Based on the results of research through interviews, observations, and documentation, it is known that the data presented is closely related to the focus studied, namely the entrepreneurial motivation of street vendors (PKL) in Seruni Beach, Bantaeng Regency. Presentation of interview data obtained related to the entrepreneurial motivation of street vendors based on several focuses then reduced based on the data obtained. Interviews were conducted with street vendors directly on Seruni Beach. To find out the entrepreneurial motivation of street vendors at Seruni Beach, this study is based on four indicators, namely, entrepreneurial spirit, creativity, innovation, and courage to take risks. The following are the results of the research obtained:

\section{There is Spirit}

Innovation is a process of human activity to find something new, related to input, process, and output, and to provide benefits. Innovation is related to something new or change. Changes in innovation can be from replacing the old system to the new system, or adding, namely not replacing or changing but adding something to the existing system.

High enthusiasm is needed by an entrepreneur in running his business because the success or failure of the business he does depends on his enthusiasm for entrepreneurship. Based on interviews conducted with traders, the spirit of entrepreneurship according to Mr. Baharuddin, as an entrepreneur of street vendors on Seruni beach, is about the enthusiasm of everyone if you want to be entrepreneurial, you must have motivation and enthusiasm first. Personally, what makes traders motivated and enthusiastic in entrepreneurship is because the merchant has four children to support. Incidentally, this trader is a former civil servant and has retired to take advantage of his spare time, the trader chooses to become an entrepreneur to increase his family's living costs. Traders choose a place for entrepreneurship in Seruni Beach because currently, the beach is one of the tourist attractions in Bantaeng Regency.

Based on the results of the interview above, it can be concluded that in entrepreneurship, one must have high motivation and enthusiasm. Entrepreneurial street vendors on Seruni Beach have almost the same motivation and enthusiasm in entrepreneurship. Entrepreneurship is a solution for those who do not have a job because by doing entrepreneurship they can support their family and fulfill their needs. Also, entrepreneurship is a hobby that can be profitable. Seruni Beach is also a strategic place and is always busy being visited, both from the Bantaeng community itself and from various regions. 


\section{Creativity}

Creativity is the main asset for an entrepreneur. Creative entrepreneurs will be able to turn challenges into opportunities. Based on the results of the interview presented by Mr. Baharuddin, as an entrepreneurial street vendor on Seruni Beach regarding the existence of creativity in entrepreneurship. can develop. In my business, I always think of making new things, like before, I renewed the appearance of my cafe chairs, which were previously ordinary plastic chairs, into a floor chair that looked floor. Because sometimes visitors like to take pictures in this place.

Based on the results of the interview above, it can be concluded that in entrepreneurship, one must have created which can be used as an opportunity to develop their own business, street vendors at Seruni Beach, Bantaeng Regency work by seeing what consumers are interested in then they create to produce something that can in demand by people.

\section{Innovation}

Innovation is creativity that is translated into something that can be implemented and provides added value to the development by understanding that innovation is hard work, breakthroughs, and kaizen (continuous improvement)

Based on the results of the interview presented by Mrs. Rahmi, as a street vendor entrepreneur on Seruni Beach, regarding the existence of innovation in entrepreneurship, traders must be able to have innovation so that their business can develop. Trader innovations that traders do by developing menus are more attractive. Then the traders also see what many people are interested in and make it look attractive so that customers don't feel bored. The merchant adds a variety of flavors from several menus, such as pisang epe which start with only brown sugar taste and are innovated into sweetened condensed milk cheese and other flavors.

Based on the results of observations I did at the innovation research location owned by street vendors on Seruni beach, they developed their business by repairing/updating their cafe products and facilities to attract more consumers' interest in their way.

\section{Courage to take risks}

Courage and the ability to take risks are the main values in entrepreneurship. If an entrepreneur is afraid to take business risks, the entrepreneur will have difficulty taking the initiative.

Based on the results of the interview presented by Mrs. Rahmi, as a street vendor entrepreneur on Seruni Beach regarding the courage to take risks in entrepreneurship, the risk that traders dare to take is the initial capital borrowed from the bank because to make a loan requires collateral. And traders had suffered losses due to the pandemic because their businesses were closed for weeks, as a result, fruit stocks that did not run out the rot and were thrown away. But everything has become a risk in entrepreneurship like this. So traders survive by reducing the stock of materials from before so as not to experience more losses, they keep reopening even though visitors are not as busy as usual.

Based on the results of these observations, it can be concluded that in entrepreneurship, one must have the courage to take and face all the risks it receives in entrepreneurship. As for the risks that have been taken by street vendors on Seruni Bantaeng beach, namely taking loans through banks and facing losses experienced by 
continuing to open and run a business that is in business even though the number of customers every day is not always the same

\section{Discussion}

\section{The existence of an entrepreneurial spirit}

Motivation is one of the triggers that can foster enthusiasm in a person within himself, especially in entrepreneurship, it is necessary to have strong motivation and enthusiasm so that something that is desired can be achieved.

In entrepreneurship, a person must have a motivational drive to arouse enthusiasm in him, especially the street vendors on Seruni Beach, Bantaeng Regency. Based on the results of observations and interviews conducted by the author with street vendors at Seruni Beach Bantaeng regarding entrepreneurial motivation because of high enthusiasm arising from the economic demands of the family to meet the necessities of life that make them self-employed as their daily work. Seruni Beach is one of the tourist attractions in Bantaeng Regency which is visited by both the people of Bantaeng Regency itself and from various other areas. This is in line with the theory according to Suryana in Asri Warnanti (2014) that high enthusiasm is needed by an entrepreneur in running his business, because the success or failure of the business that is carried out depends on the enthusiasm for entrepreneurship.

This is proven by everyone if you want to be entrepreneurial you must have motivation and enthusiasm first. The thing that motivates traders in entrepreneurship is because the average trader has children who must be financed and to take advantage of their free time traders choose to become entrepreneurs to add and cover the cost of living in their family.

From this, the Bantaeng Branch of Bank Rakyat Indonesia (BRI) collaborates with the Bantaeng Cooperative and UKM Office, by handing over 40 carts to street vendors (PKL) who are in the Seruni Beach culinary area with the hope that the street vendors can be more organized and able to improve the community's economy to trigger traders to be more enthusiastic in running their business.

From the observations made, the enthusiasm possessed by street vendors on Seruni Bantaeng Beach to be entrepreneurial arises because of the economic demands that must be fulfilled in financing daily life.

\section{Creativity}

Creativity is an idea or ability that a person has to be able to produce something of value. In this case, traders on Seruni Beach are very important to have creativity because it is one of the initial capital in developing their business

Based on the results of observations of interviews conducted by the author with street vendors at Seruni Beach, Bantaeng Regency, the existence of creativity is one of the important things that an entrepreneur must-have. On Seruni beach, street vendors are creative by always trying to think of new things to offer, apart from the menu, facilities are also important if they are made into an attractive place because in general people usually make this place also a place to take selfies. fulfilling social media needs, this is in line with 
the theory of suryana in Asri Warnanti (2014) Creativity is the main asset for an entrepreneur. Creative entrepreneurs will be able to turn challenges into opportunities.

This is proof that creativity is very important because, with creativity, traders can think about what they want to be a menu in their business, and also how to make the place as comfortable as possible for customers. One of the ideas made by a trader with chair facilities, which was originally only a plastic chair and then changed to a unique chair. As well as traders also offer contemporary snacks which are commonly called corndog sausages which are in great demand by the public lately.

Based on the results of observations made on street vendors on Seruni Beach, Bantaeng Regency, they have good creativity because with the creativity they can develop the menus that are served and make their business places more attractive.

\section{Innovation}

Innovation is a creation that a person has to develop his business so that it is more developed. In entrepreneurship, especially traders on Seruni Beach, innovation must be needed so that traders can compete with other entrepreneurs and adjust to trends or according to people's tastes to maintain their business existence because if an entrepreneur does not innovate, the resulting product cannot develop.

Based on the results of observations and interviews conducted by the author with street vendors at Seruni Beach, Bantaeng Regency regarding innovations in entrepreneurship, it is known that traders at Seruni Beach develop their business by improving / changing menu appearance, providing promos, issuing breakthroughs both in terms of food menus and drinks and from facilities that are made comfortable and attractive to be used as a comfortable place to relax. This is in line with the theory according to Suryana in Asri Warnanti (2014) Innovation is creativity which is translated into something that can be implemented and gives added value to development by understanding that innovation is hard work, breakthrough, and kaizen (continuous improvement).

This is proven as an entrepreneur, a trader must be able to have innovation so that his business can develop. Innovations made by traders by developing menus to be more dancing, for example making the menu display more attractive so that customers don't feel bored, EPE bananas, which initially only had 1 taste variant, were then innovated by providing other flavors, namely sweetened condensed milk and cheese and flavor variants. other.

From observations, it was found that the existence of innovations in entrepreneurship in street vendors on Seruni Beach, Bantaeng Regency, arose from the ideas of traders who always tried to keep up with the times or trends and something that people generally wanted.

\section{Courage to take risks}

The courage to take risks is one of the keys to starting a business because in this case, the entrepreneur must have the courage to accept risks in entrepreneurship. In Seruni Beach, Bantaeng Regency, traders must have the courage to face all kinds of risks they will face continuing their business.

Based on the results of observations and interviews conducted by the author with street vendors at Seruni Beach, Bantaeng Regency, regarding the courage to take risks, such as what happens in entrepreneurship is a natural thing, and some traders on the beach before becoming an entrepreneur, traders take money. bank to be used as the main capital and to 
106 Pinisi Business Administration Review
Vol. 2, No. 2, September 2020, Pages 100-108

face and then cover back all the risks that traders take by the way traders keep trying and be more active in running their entrepreneurship. This is in line with the theory according to Suryana in Asri Warnanti (2014). Courage and the ability to take risks are the main values in entrepreneurship. If an entrepreneur is afraid to take business risks, the entrepreneur will have difficulty taking the initiative.

This was proven by a trader when he first opened a business to get additional capital, the trader was brave enough to take risks by borrowing money from the bank to use it as initial capital for his business. From the results of observations made regarding the courage in taking risks, street vendors on Seruni Beach can face these risks by continuing to try in running their business.

\section{CONCLUSION}

Based on the results of the research and discussion described in the previous chapter, the spirit of entrepreneurship is a solution for those who do not have other jobs, and one of the beneficial opportunities to develop a hobby. This is proven because of the encouragement that arises and comes from themselves (internal factors) and also from outside themselves (external factors). Creativity is an important factor in developing a business. Creative entrepreneurs will be able to turn a challenge into an opportunity. This has been proven by them being able to develop the menus that are served and to make their place of business more attractive. In innovation, an entrepreneur implements and provides added value to the development by understanding that innovation is a sense of work, breakthroughs, and continuous improvement. This is evidenced by the street vendors who develop their business by always trying to keep up with the times or trends and who is currently the interest of people in general. In terms of being brave enough to take risks, this is the main value of entrepreneurship. If an entrepreneur is afraid to take business risks, the entrepreneur will have difficulty taking the initiative. This is evidenced by street vendors with the courage they take for initial capital, they take loans through the bank and face losses by trying to run their business so that they can cover all these risks. Return to the results of the business they are doing, even though the number of customers visiting is not always the same every day.

\section{REFERENCES}

Alfian, M., Niswaty, R., Darwis, M., Arhas, S. H., \& Salam, R. (2019). Motivasi Kerja Pegawai pada Sekretariat Dewan Perwakilan Rakyat Daerah Kabupaten Gowa. 1, 35-44.

Amorós, J. E., Cristi, O., \& Naudé, W. (2020). Entrepreneurship and subjective well-being: Does the motivation to start-up a firm matter? Journal of Business Research. https://doi.org/https://doi.org/10.1016/j.jbusres.2020.11.044

Aparicio, S., Audretsch, D., \& Urbano, D. (2021). Why is export-oriented entrepreneurship more prevalent in some countries than others? Contextual antecedents and economic consequences. Journal of World Business, 56(3), 101177. https://doi.org/https://doi.org/10.1016/j.jwb.2020.101177 
Bachri, B. S. (2010). Meyakinkan Validitas Data Melalui Triangulasi Pada Penelitian Kualitatif. Teknologi Pendidikan, 10, 46-62.

Bojica, A. M., \& Fuentes, M. del M. F. (2012). Knowledge acquisition and corporate entrepreneurship: Insights from Spanish SMEs in the ICT sector. Journal of World Business, 47(3), 397-408. https://doi.org/https://doi.org/10.1016/j.jwb.2011.05.007

Cullen, U. A., \& De Angelis, R. (2020). Circular entrepreneurship: A business model perspective. Resources, Conservation and Recycling, 105300. https://doi.org/https://doi.org/10.1016/j.resconrec.2020.105300

de Guimarães, J. C. F., Severo, E. A., \& de Vasconcelos, C. R. M. (2018). The influence of entrepreneurial, market, knowledge management orientations on cleaner production and the sustainable competitive advantage. Journal of Cleaner Production, 174, 1653-1663. https://doi.org/https://doi.org/10.1016/j.jclepro.2017.11.074

Douglas, E., \& Prentice, C. (2019). Innovation and profit motivations for social entrepreneurship: A fuzzy-set analysis. Journal of Business Research, 99, 69-79. https://doi.org/https://doi.org/10.1016/j.jbusres.2019.02.031

Ferreira, A. da S. M., Loiola, E., \& Gondim, S. M. G. (2017). Motivations, business planning, and risk management: entrepreneurship among university students. $R A I$ Revista de Administração e Inovação, 14(2), 140-150. https://doi.org/https://doi.org/10.1016/j.rai.2017.03.003

Hisrich, R. D., Peters, M. P., \& Shepherd, D. A. (2002). Entrepreneurship. New York: McGraw Hill.

Holcombe, R. G. (1998). Entrepreneurship and economic growth. The Quarterly Journal of Austrian Economics, 1(2), 45-62. https://doi.org/10.1007/s12113-998-1008-1

Hoque, A., \& Awang, Z. (2019). Does gender difference play moderating role in the relationship between entrepreneurial marketing and Bangladeshi SME performance? Accounting, 5(1), 35-52.

Muhammad Zainul Madjid. (20212). PENGARUH PEMBELAJARAN KEWIRAUSAHAAN, INTERNALISASI NILAI KEWIRAUSAHAAN DI KELUARGA DAN MOTIVASI MINAT BERWIRAUSAHA. 7, 10.

Naoumi marie tando. (2013). Kewirausahaan (1 ed.). Manado: In Media.

Nasrullah, M., Salam, R., Pratiwi, D., \& Niswaty, R. (2017). Motivasi Kerja Pegawai Di Kantor Keyahbandaran Utama Makassar. Jurnal Ilmiah Manajemen Dan Bisnis, 18(2), 206-211.

Nasution, H. N., Mavondo, F. T., Matanda, M. J., \& Ndubisi, N. O. (2011). Entrepreneurship: Its relationship with market orientation and learning orientation and as antecedents to innovation and customer value. Industrial Marketing Management, 40(3), 336-345. https://doi.org/https://doi.org/10.1016/j.indmarman.2010.08.002

Porter, D. (2009). Entrepreneurship. In Routledge Companion to Sports History. https://doi.org/10.4324/9780203885413-20

Reski, M., Niswaty, R., \& Saleh, S. (2018). Motivasi Belajar Siswa di Madrasah Aliyah 
$108 \begin{array}{r}\text { Pinisi Business Administration Review } \\ \text { Vol. 2, No. 2, September 2020, Pages 100-108 }\end{array}$

Annur Nusa Kecamatan Kahu Kabupaten Bone. Jurnal Office, 4(1), 25-32.

Rumelt, R. P. (1987). Theory, strategy, and entrepreneurship. The competitive challenge, 137(158), 1-22.

Scherdin, M., \& Zander, I. (2011). Art entrepreneurship. In Art Entrepreneurship. https://doi.org/10.4337/9781849808507

Shane, S., \& Venkataraman, S. (2007). The promise of entrepreneurship as a field of research. In Entrepreneurship: Concepts, Theory and Perspective. https://doi.org/10.1007/978-3-540-48543-8_8

Sirait, E. J. M., Arhas, S. H., \& Suprianto, S. (2019). The Influence of Assignment of Lecturers at School (ALS) Program on Students Learning Motivation in Tarakan City. Jurnal Ad'ministrare, 6(1), 79-88.

To, C. K. M., Guaita Martínez, J. M., Orero-Blat, M., \& Chau, K. P. (2020). Predicting motivational outcomes in social entrepreneurship: Roles of entrepreneurial selfefficacy and situational fit. Journal of Business Research, 121, 209-222. https://doi.org/https://doi.org/10.1016/j.jbusres.2020.08.022 